\title{
STUDY OF “RUSUN” TYPOLOGY BASED ON THERMAL COMFORT ANALYSIS USING SOFTWARE SIMULATION METHOD IN RUSUNAWA TYPE-30
}

\author{
Nurina Vidya Ayuningtyas*, Istiana Adianti*, Jatmika Adi Suryabrata** \\ *) Arsitektur, Widya Mataram Universitas, Dalem Mangkubumen KT III/237 \\ Yogyakarta55132 \\ **) Arsitektur, Universitas Gadjah Mada, Jalan Grafika 2 Yogyakarta 55284 \\ email : nurina.vidya@gmail.com
}

\begin{abstract}
Simple rental Flats (Rusunawa) is the government's role in overcoming the need for housing, so that the quality of housing becomes more feasible. The feasibility can be seen from the thermal side of the flat so that the occupants of the flat are more comfortable living in it. This research simulates with software in low-rise apartment buildings so that they get a typology of effective and thermally comfortable flatpanel design. The typology can be a directive for architects in designing a flat which prioritizes thermal comfort for the occupants as well as a flat design that is quite effective and profitable for developers. The software used is Autodesk Ecotect Analysis, Energy Plus, CFD and Dialux. With the simulation software, the double load corridor layout is more effective in terms of development costs and still has a good air exchange. While the orientation of the North-South building is better so that it can reduce the amount of openings from the direction of the coming sunlight.
\end{abstract}

Keywords: Rusunawa; Thermal Comfort; Simulation.

\section{INTRODUCTION}

The rapid growth of the urban population from year to year has led to an increase in demand for housing needs. Residence or home is a basic need that will continue to grow by the cycle of human life.

According to Law no.16 of 1985 and PP no.4 of 1988 concerning Flats, it is stated that Flats are multi-story buildings built in an environment, divided into functionally structured sections into horizontal and vertical directions and constitute units each unit can be owned and used separately, especially for dwellings, which are equipped with shared parts, shared objects and shared land. Whereas what is meant by simple flats (runaway) are simple flats whose ownership is in the rental system. 
Rental simple flats are government programs in overcoming some of the existing settlement problems, among others to improve the quality of the community in providing decent housing following regional spatial planning, tackling the urban environment that develops unhealthy (slums), and helps low-income communities ( MBR) in fulfilling a residence.

This situation is a concern for the government to create prosperity for all its people. One approach to overcoming this problem is to make housing for lowincome people. But housing for the poor in urban areas is not easy to implement due to obstacles that must be overcome by local governments such as; 1) Empty land that is difficult to obtain; 2) Expensive land price; 3) vacant land is not necessarily filled in view that transportation is not cheap to work; 4) resettlement is difficult to relocate even on government-owned land for various reasons. From this situation, it seems that it is necessary to learn from Jakarta who built Flats amid densely populated settlements in the form of Own Flats or Rent Flats (Pasya, 2012: 12).

When talking about thermal comfort in space certainly will not escape by making the temperature indicator as a benchmark. The actual indicator must be considered in achieving the level of human comfort that inhabits the space is the Operative Temperature value, where the Operative Temperature is the average value of the sum of air temperature and mean radiant temperature and is the temperature that is felt directly by human skin (Jain, 2011). Also, the pattern of wind movement plays an important role in efforts to produce a healthy disposition in the flat area.

This research was conducted to find out the typology of effective and thermally comfortable flat design. Also, it is to get input regarding effective flat design for land use to cost-effective.

The results of this study are expected to be able to give direction to the architects in designing a flat that prioritizes thermal comfort to the occupants as well as a flat design that is quite effective and profitable for developers.

\section{THEORY / RESEARCH METHODS}

Flats design must meet specific planning criteria which consist of several studies in the form of building layout; shape, space and arrangement; structure; circulation and pedestrian; lighting; ventilation; piping; fire extinguisher system; lightning rod; transportation; waste disposal system; and telephone network.

1. A simple house (rusunawa) that is built can be in the form of one block (monoblock) or two blocks (twin blocks). Plan the form as much as possible symmetrical, simple, functional, efficient, and meets the requirements of airing and lighting. For plans of apartment buildings in the form of T, L, and $U$ with a length of more than $50 \mathrm{~m}$, there must be dilatation. The need for a minimum of $18 \mathrm{~m} 2$ residential units with a width of at least $3 \mathrm{~m}$ and a maximum shared space area of $30 \%$ of the total floor area of the building (Ministry of Public Works, 2007).

2. In terms of structure, components, and the use of building materials for flats, the strength and durability must be calculated for a minimum of 20 to 50 years by applicable regulations. Building materials for walls that are not structures must 
be able to withstand the load. The load is by the function of the exterior wall and has a strong bond with the building structure. Dilation installation is required if the floor plan is too long or not symmetrical (Ministry of Public Works, 2007). As much as possible circulation must be able to provide easy and clear achievements and vertical motion and width of the road suitable for the achievement of service vehicles. The provision of existing parking may not reduce the KDH area (Green Area Coefficient) which has been determined with a ratio of 1 vehicle parking lot for every 5 residential units. Pedestrian width that is made at least $90 \mathrm{~cm}$ on 1 or 2 sides of the road shoulder or road pavement (Ministry of Public Works, 2007).

3. In terms of lighting, flats should have openings for optimal natural lighting with the best lighting around 8:00 to 16:00. There are 3 natural lighting factors during the day that need to be considered when light enters the building, namely the sky component, the outside reflection component, and the inner reflection component (National Standardization Agency, 2001a). Artificial lighting standards are at least 50 lux for rooms used for work and 20 lux for non-work spaces, such as stairs or corridors (National Standardization Agency, 2001b). The number of ventilation openings is not less than $5 \%$ of the floor area of one residential unit. Ventilation openings for natural ventilation should face a yard of an appropriate size or an area that is open up the open terrace, and a parking lot (Ministry of Public Works, 2007).

4. In the electricity grid system, each household unit must be able to be served with a minimum electrical power of 450 VA per person and for environmental facilities at $40 \%$ of the total household needs. Each residential unit must have at least 1 point of measuring device (electric meter), 1 point of outlet, 1 point of switch, and 2 points of light. The existing street lighting has strong lighting of around 500 lux with a height of more than 5 meters from the face of the ground (National Standardization Agency, 2004). Horizontal transportation in the form of a corridor can be placed in the middle or edge of the building mass with a minimum width of $5 \times 3 \mathrm{~m}$ or $1.2 \mathrm{~m}$. Buildings that have 5 floors can use the stairs as vertical transportation. More than 5 floors must use an elevator. The planned stairs have a minimum width of $120 \mathrm{~cm}$ with a landing width of at least $120 \mathrm{~cm}$ and a stepping width of the stairs of at least $22.5 \mathrm{~cm}$. Railing for stairs has a minimum height of $110 \mathrm{~cm}$ (Kementerian Pekerjaan Umum, 2007).

5. Solid waste disposal systems are installed taking into account the storage facilities and types. The intended rubbish container is a waste storage place in each residential unit of flats and garbage canals placed inside or outside the residential unit. These containers can be made of permanent or semi-permanent materials, are odor-proof, impermeable, and do not rust easily (Ministry of Public Works, 2007).

When talking about thermal comfort in space certainly will not escape by making the temperature indicator as a benchmark. The actual indicator that must be considered in achieving the level of human comfort that occupies the space is the Operative Temperature value, where the Operative Temperature is the average value of the sum of air temperature and mean radiant temperature and is the temperature felt directly by human skin (Jain, 2011). 


$$
t_{o}=\frac{\left(t_{a}+t_{m r}\right)}{2} \quad \begin{aligned}
& t_{o}: \text { Operative Temperature } \\
& t_{a} ; \text { Air temperature } \\
& t_{m r}: \text { Mean Radian Temperature }
\end{aligned}
$$

So far, in addition to the heat and temperature indicators, what will be examined in this study is related to the amount of heat received by the building envelope, then the size of the wind flow into the flat units and the size of natural light that can illuminate the building unit.

\section{Research Methods}

In general, the term simulation is defined as a performance representation of a process or system, where the representation is carried out using a model that has characteristics similar to real conditions. However, within the scope of building simulations, the system in which the performance will be represented can have a more specific context, in the form of space, building envelope, or building construction details and not always in the form of a whole building. This depends on the scope to be analyzed.

Software used in this study includes Ecotect, Energy Plus, CFD and Dialux. Ecotect is used for total radiation analysis to determine the amount of radiation exposure in each area of the building envelope. Then, overall it can be seen, whether the shape and orientation of this building are good enough to minimize the amount of radiation exposure that falls on the surface of the building envelope. The simulation is done by taking a flat model to represent the whole model because all the flat has the same shape. Energy Plus is used as a comparative analysis of the character of the external heat gain to find out how much sun exposure is received by the building and how much influence it has on the building. The calculation is done by modeling each of the towers, then the model is calculated using simulation with the help of computer software. In addition to location and orientation, simulations were also carried out using different wall and glass materials for each unit. This CFD is used to analyze the natural airflow in residential units and Dialux is used as a daylight calculation simulation that aims to determine the intensity of light that can enter the room. The simulation can be displayed mapping the intensity of natural light entering the room.

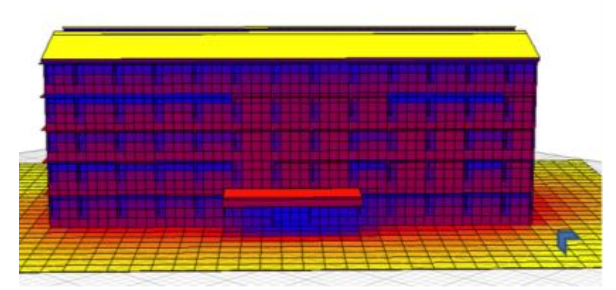

(a)

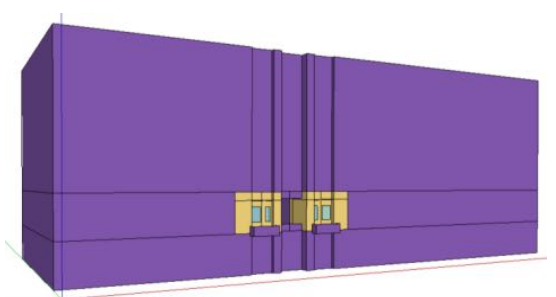

(b)

Figure 1. (a) Ecotect Simulation Results ; (b) Energy Plus Simulation Image Sources : Author Analysis, 2019 


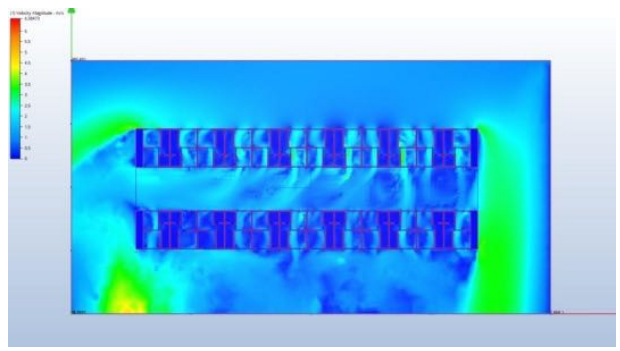

(a)

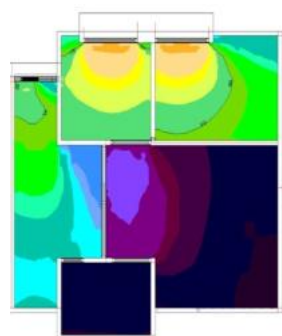

(b)

Figure 2. (a) CFD Simulation Results. (b) Dialux Simulation Results. Sources : Author Analysis, 2019

\section{RESULTS AND DISCUSSION}

This study was conducted using a simulation of some of the software mentioned above. The analysis included solar radiation analysis, external heat gain analysis, natural ventilation analysis, and daylight analysis.

\section{Analysis of solar radiation}

The simulation analysis of Solar Radiation was carried out on March 5, June 25 and December 24, according to the position of the sun's peak towards the building. The specified time is from 8 am to $18 \mathrm{pm}$. Total radiation analysis was carried out to determine the amount of radiation exposure in each area of the building envelope. Then, overall it can be seen, whether the shape and orientation of this building is good enough to minimize the amount of radiation exposure that falls on the surface of the building envelope.
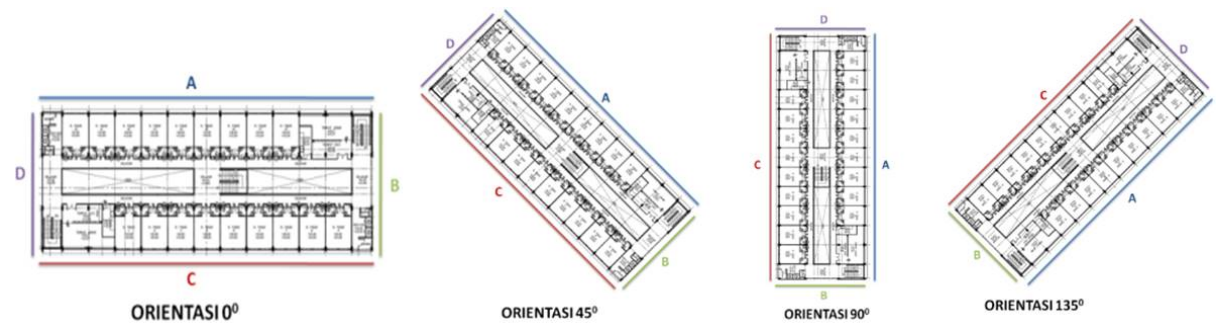

Figure 3. Alternative Orientation of T-30 Flats Simulation Model Sources : Author Analysis, 2019

Solar Radiation Simulation is simulated with 4 kinds of orientation, namely buildings with orientation 00 (north-south), 450 (northeast-southwest), 900 (eastwest), and 1350 (southeast-northwest). Each side of the building will be compared to the acquisition of solar radiation between the different orientations. 


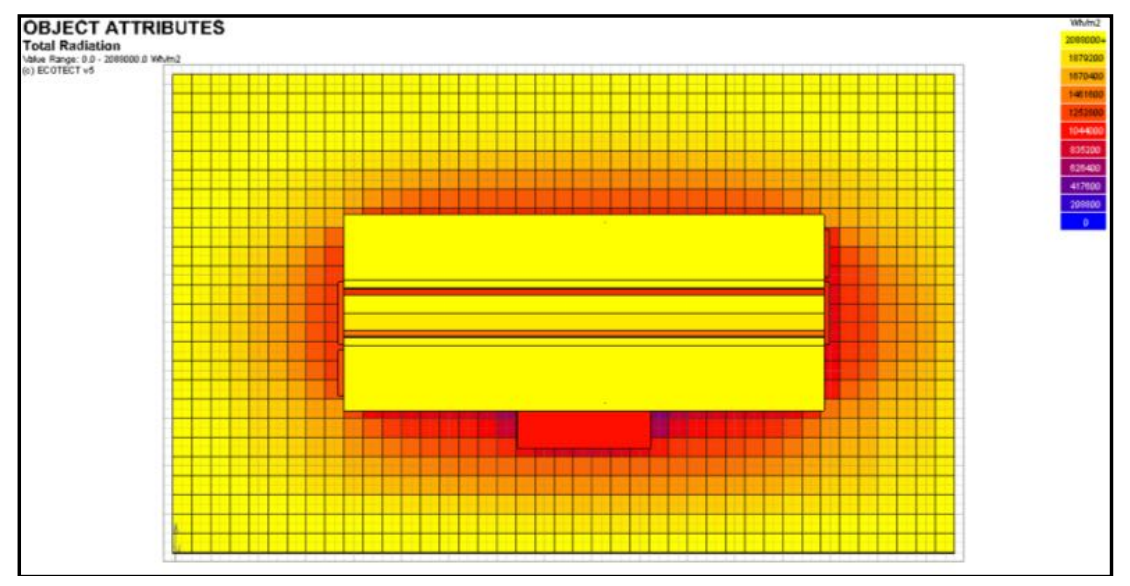

Figure 4. Analysis of solar radiation Sources : Author Analysis, 2019

Based on the simulation results it appears that the 00 oriented building receives the highest solar radiation on the $\mathrm{D}$ side (west), followed by the A side (north) and the B side (east), while the lowest solar radiation is received by the $\mathrm{C}$ side (south). In buildings that are oriented 450 receive the highest solar radiation on the D side (northwest), followed by the $\mathrm{C}$ side (southwest) and side A (northeast), while the lowest solar radiation is received by the B side (southeast). In buildings with 900 orientation, solar radiation is highest on the $C$ side (west), followed by the $\mathrm{D}$ side (north) and the A side (east), while the lowest solar radiation is received by the B side (south). Whereas in buildings which are oriented in 1350 receive the highest solar radiation on the $\mathrm{C}$ side (northwest), followed by the $\mathrm{B}$ side (southwest) and the $\mathrm{D}$ side (northeast), while the lowest solar radiation received by the A side (southeast).

Side $\mathrm{A}$ and side $\mathrm{C}$ are much wider than side $\mathrm{B}$ and side $\mathrm{D}$ so that if both sides receive solar radiation with high intensity, the thermal conditions in the building will be hotter than if side $\mathrm{B}$ and side $\mathrm{D}$ receive high intensity solar radiation. Based on the comparison of solar radiation acquisition on each side of the building with different orientation, it appears that buildings with 900 and 1350 orientation receive the highest solar radiation on the $\mathrm{C}$ side. Thus the thermal conditions of the two building models are hotter than the 00 and 450 oriented models.

Table 1. Heat Radiation Gain Result on Each Side of the Building

\begin{tabular}{|c|c|c|c|c|}
\hline ORIENTASI & UTARA & $\begin{array}{l}\text { TIMUR } \\
\text { LAUT }\end{array}$ & TIMUR & TENGGARA \\
\hline External Heat Gain (W) & 651.45 & 764.11 & 826.20 & 676.24 \\
\hline External Heat Gain (W/m2) & 58.17 & 68.22 & 73.77 & 60.38 \\
\hline $\begin{array}{l}\text { Wall surface inside } \\
\text { temperature }(\mathrm{C})\end{array}$ & 30.36 & 31.32 & 31.83 & 30.67 \\
\hline
\end{tabular}


Table 2. Heat Radiation Gain Result on Each Side of the Building

\begin{tabular}{ccccc}
\hline ORIENTASI & SELATAN & BARAT DAYA & BARAT & BARAT LAUT \\
\hline $\begin{array}{c}\text { External Heat Gain }(\mathrm{W}) \\
\text { External Heat Gain }\end{array}$ & 537.98 & 684.07 & 833.50 & 767.86 \\
$\quad$ & & & \\
(W/m2) & 48.03 & 61.08 & 74.42 & 68.56 \\
$\begin{array}{c}\text { Wall surface inside } \\
\text { temperature (C) }\end{array}$ & 29.59 & 30.27 & 31.12 & 30.79 \\
\hline \multicolumn{4}{r}{ Sources : Author Analysis, 2019 } \\
\end{tabular}

The simulation of the acquisition of external heat gain on each side of the building envelope shows that the highest acquisition of external heat gain is obtained by building walls facing east and west, and the lowest acquisition of external heat gain is obtained by building walls facing north and south. While the walls of the building facing southeast and northwest and northeast and southwest get an external heat gain of almost the same magnitude.

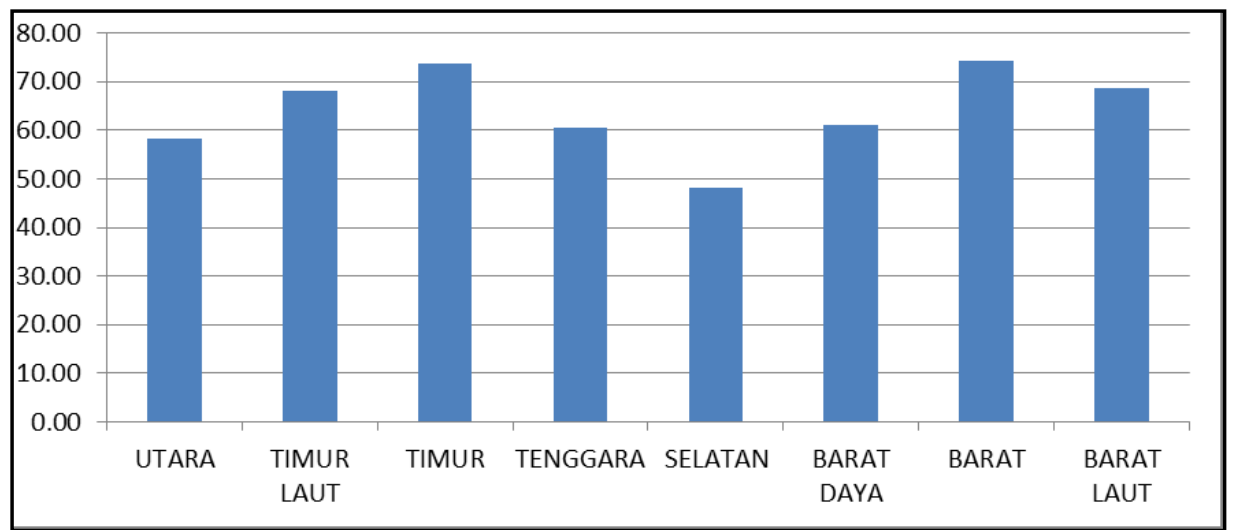

Figure 5. Comparison of External Heat Gain Value in Each Orientation Sources : Author Analysis, 2019

Thus, the orientation of the building is best if the wide side of the wall faces north-south because it can minimize the heat received by the building. Simulation results show that the surface wall inside the north-facing wall is $30.36^{\circ} \mathrm{C}$ and the south-facing wall is $29.59^{\circ} \mathrm{C}$, far lower than the wall surface inside wall facing east temperature is $31.83^{\circ} \mathrm{C}$ and the west-facing wall is $31.12^{\circ} \mathrm{C}$. 


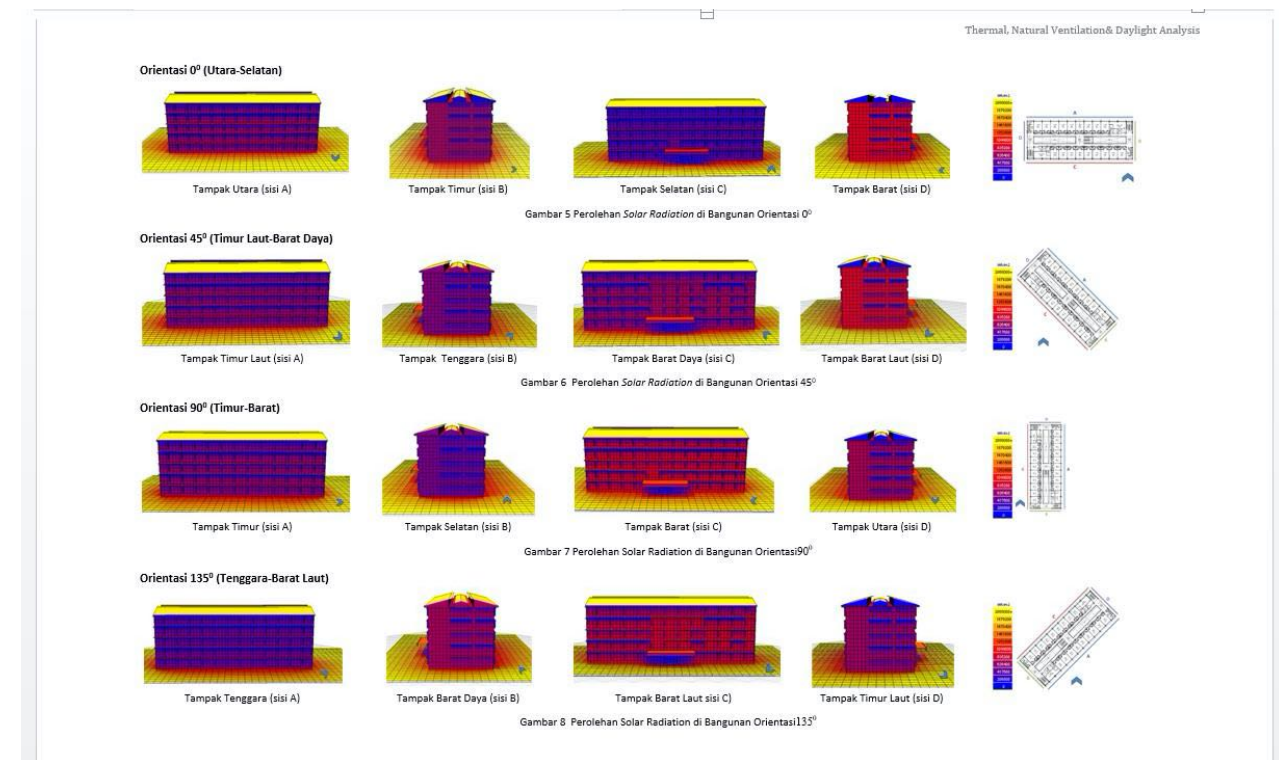

Figure 6. Acquisition of Solar Radiation in Orientation Buildings $135^{0}$ Sources : Author Analysis, 2019

\section{Analysis of external heat gain}

Comparative analysis of the character of the external heat gain is done to find out how much sun exposure is received by the building and how much influence it has on the building. Human thermal comfort is not only determined by the temperature of the room air (Air Temperature), but also by the average temperature of the interior surface called the Mean Radiant Temperature (MRT). The combined effect of room temperature and MRT on human thermal comfort is referred to as Operative Temperature, which is the temperature sensation felt by the human body that determines the level of thermal comfort.

\section{Building Geometry Model}
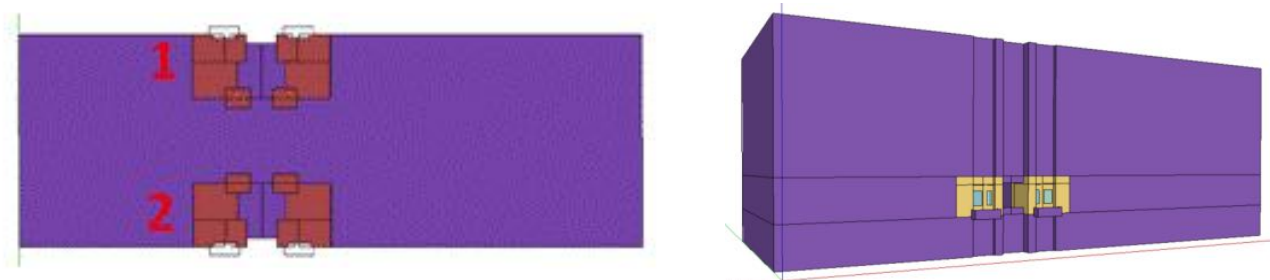

Figure 7. Layout Model and Geometry of T-30 Flats Sources : Author Analysis, 2019 

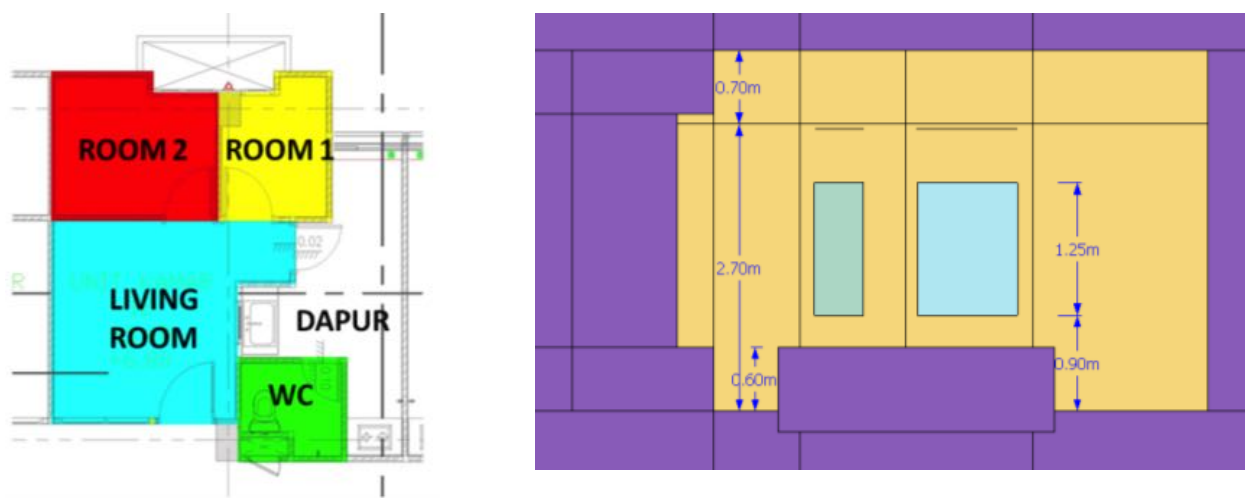

Figure 8. Unit Plan and Elevation Details Sources : Author Analysis, 2019

T-30 Flats Arrangement is performed using 2 units with different orientations. This T-30 flat has a floor to floor height as high as $3.40 \mathrm{~m}$ with a height of functional zone (space under the ceiling) as high as $2.70 \mathrm{~m}$. Window openings as high as $0.9 \mathrm{~m}$ from the floor and have a height of $1.25 \mathrm{~m}$. T-30 Rusun Unit consists of 5 zones, namely Room 1, Room 2, Living room, Kitchen and Toilet. In the simulation model, the kitchen zone does not simulate because it is an open space.

Table 2. Comparison of external heat gain simulation results

\begin{tabular}{|c|c|c|c|c|c|c|c|c|c|c|c|c|c|c|c|c|c|c|}
\hline & ORIENTATION & & NORT & & & & SOU: & & & & NORTH & AAST & & & SOUTH W & EST & & \\
\hline & UNIT & & 1 & & & & 2 & & & & 1 & & & & 2 & & & \\
\hline & WALL & teb & & prec & & beb & & preas & & hebe & & prec: & & heb & & prece & & \\
\hline & GLASS & dear & panasap & deas & panasap & clear & panasap & dear & panasap & dear & panasap & clear & \begin{tabular}{|l|l|} 
panassp \\
\end{tabular} & dear & panasap & deas & panassp & \\
\hline Wall Surface & e inside Temperature (C) & 31.62 & 31.05 & 41.01 & 40.71 & 30.52 & 30.17 & 38.30 & 38.12 & 31.43 & 30.98 & 41.18 & 40.90 & 32.19 & 31.61 & 42.80 & 4249 & \\
\hline & & & & & & & & & & & & & & & & & & \\
\hline Double log & S No vod & & & & & & & & & & & & & & & & & \\
\hline & External Heat Gain (W) & 48066 & 4209 & 651.45 & 601.33 & 385.08 & 343] & 537.96 & 502.91: & 566.52 & 485.57| & 764.11 & 693.5 & 51836 & 454.14 & 69407 & 631.62 & \\
\hline ROOM & & & & & & & & & & & & & & & & & & \\
\hline & $\operatorname{MRT}(C)$ & 28.15 & $27 \pi$ & 2894 & 2864 & 27.68 & 27.4 & 28.42 & 28.2 & 28.52 & 2816 & 29.47 & 29.1 & 28.36 & 27.94 & 29.14 & 2879 & \\
\hline Single loas: & I with void & & & & & & & & & & & & & & & & & \\
\hline & External Heat Gain (W) & 482.7 & 422.87 & 658.00 & 607.68 & 385.86 & 343.76 & 540.58 & 505.45 & 568.28 & 487.12 & 769.69 & 698.91 & 519.83 & 455.53 & 688.47 & 635.85 & \\
\hline ROOM & & & & & & & & & & & & & & & & & & \\
\hline & $\operatorname{MRT}(\mathrm{C})$ & 28.16 & 27.78 & 28.98 & 28.68 & 27.69 & 27.41 & 8.43 & 28.21 & 28.63 & 28.17 & 29.50 & 29.13 & 28.37 & 27.95 & 29.13 & 28.81 & \\
\hline
\end{tabular}

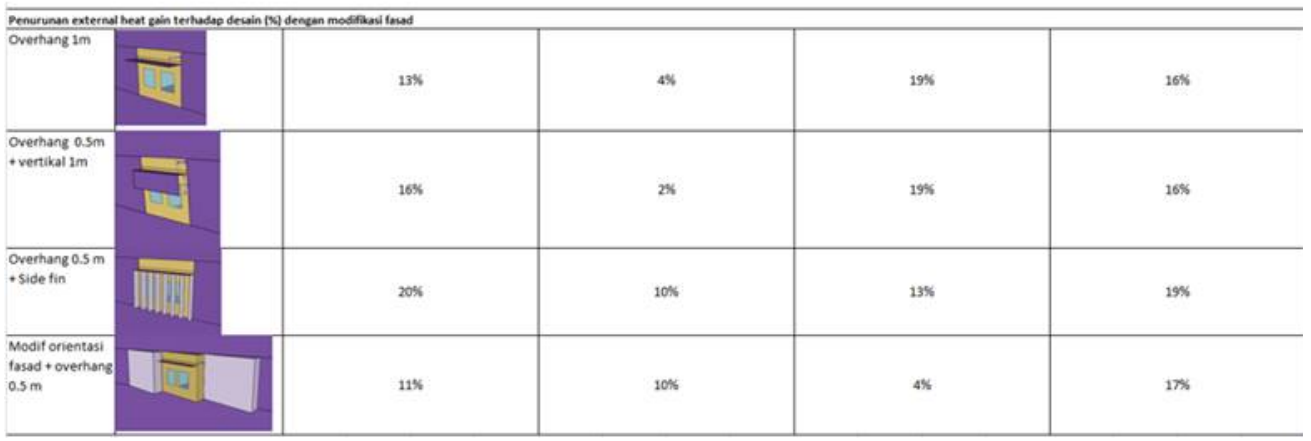

Sources : (Author Analysis, 2019)

Table 2. Comparison of external heat gain simulation results 
Nurina: STUDY OF "RUSUN" TYPOLOGY BASED ON THERMAL COMFORT ANALYSIS USING SOFTWARE SIMULATION METHOD IN RUSUNAWA TYPE-30

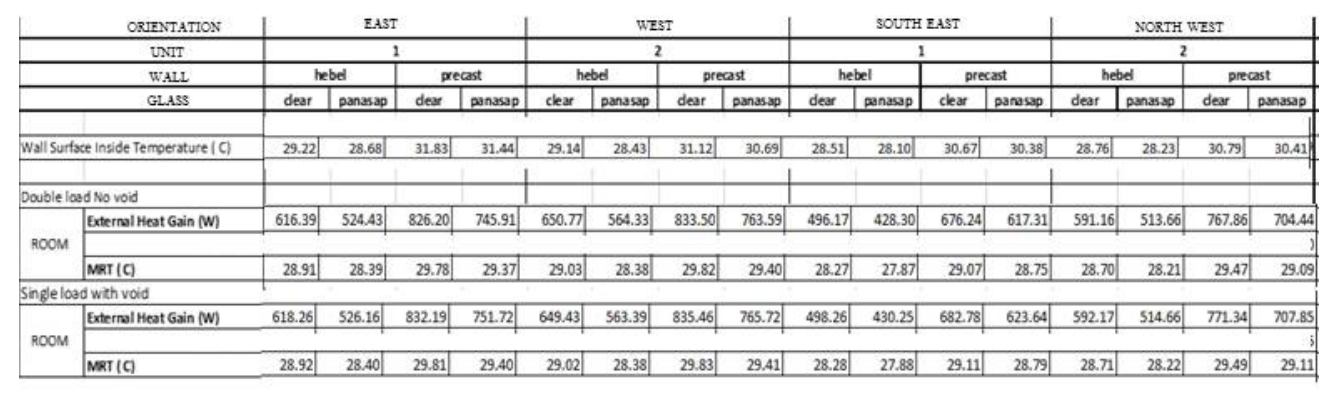

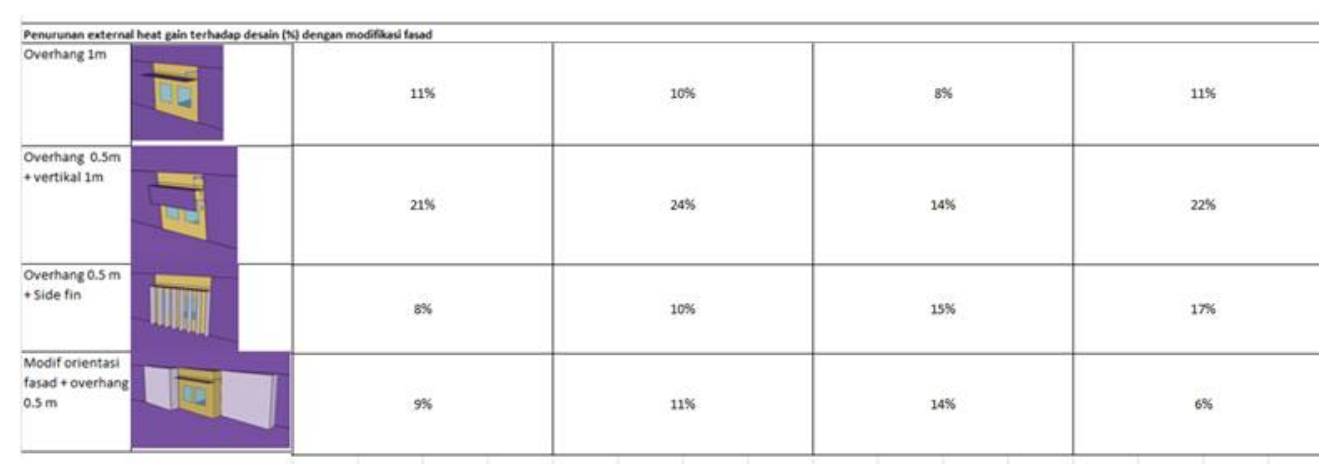

Sources : (Author Analysis, 2019)

The best composition of building envelope material is to use lightweight brick wall material and tinted glass (Panasap) windows. This is because the acquisition of external heat gain light brick walls and window glass tinted glass (Panasap) is smaller than the combination of other materials. The U-value on the precast wall is higher $(4,417 \mathrm{~W} / \mathrm{m} 2 \mathrm{~K})$ so that the ability to absorb and carry heat is higher than the light brick u-value $(1,231 \mathrm{~W} / \mathrm{m} 2 \mathrm{~K})$. And also the SHGC value of clear glass is higher (0.839) than tinted glass (Panasap) (0.584), so the ability to transmit heat from solar radiation is greater than tinted glass (Panasap). If you see the results of the value of the wall surface inside the temperature, the temperature difference looks significant when using lightweight bricks compared to using precast. The value of the wall surface inside the temperature using the largest clear brick light glass 32.29 ${ }^{\circ} \mathrm{C}$ while on the glass wall precast clear $43.09^{\circ} \mathrm{C}$. If using a lightweight brick wall, tinted glass (Panasap) wall surface inside the highest temperature is $31.70^{\circ} \mathrm{C}$ and precast glass tinted glass (Panasap) is $42.79{ }^{\circ} \mathrm{C}$. Then the recommended combination of materials is recommended to use lightweight brick walls and tinted glass (Panasap). Based on the orientation of units oriented to the south receive the lowest heat gain compared to other orientations. The south side receives the lowest external heat gain because the south side receives the least amount of solar radiation compared to 7 other orientations. This is because the average solar radiation facing south receives 110.55-watt solar radiation. For the average amount of solar radiation in other orientations, among others: 1) North: 152.08 watts ; 2) North East: 168.22 watts ; 3) East: 178.54 watt ; 4) South East: 138.33 watts ; 5)South West: 164.90 watts ; 6) West: 219.38 watt ; 7) North West: 197.02 watt 


\section{Analysis of natural ventilation}

Natural ventilation analysis is performed to determine the movement of airflow in the room. The airflow in question is the flow of air from outside the room that enters the room through openings (doors, windows, and vents) so that air changes occur in the room. With the change of air in the room is expected to achieve thermal comfort for the occupants of the room. The analysis was carried out on the flat buildings for students and single workers, workers with families, MBR, and Islamic boarding schools.

\section{Natural Ventilation Simulation Model}

Natural ventilation analysis is calculated using CFD (Computational Fluid Dynamic) software to determine the air flow that occurs in buildings. CFD software is able to calculate and display an analysis of the direction of air flow, the speed of air flowing, and air pressure at each point through which the air flow is passed. in this case, the air flow analyzed is the air flow that occurs in the building. In this simulation the T-30 Flats model represents a unit consisting of several rooms. The flow coming from south east side and then enter pass the building

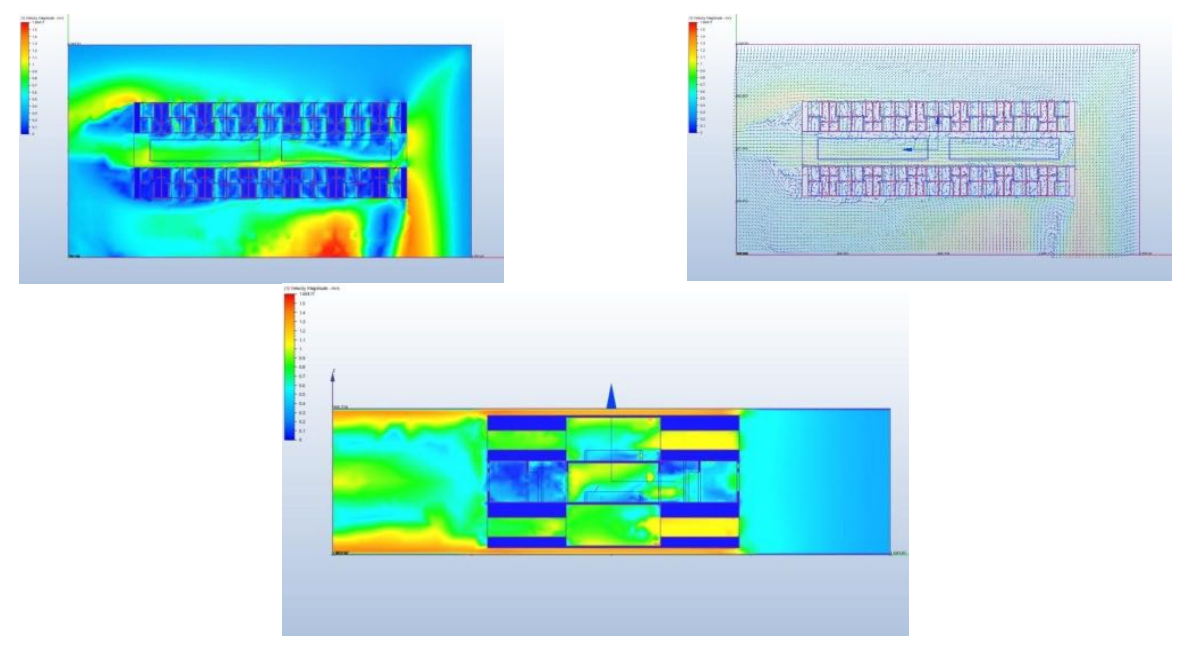

Figure 9. Natural Ventilation Analysis on Single Load Corridor Sources : Author Analysis, 2019 


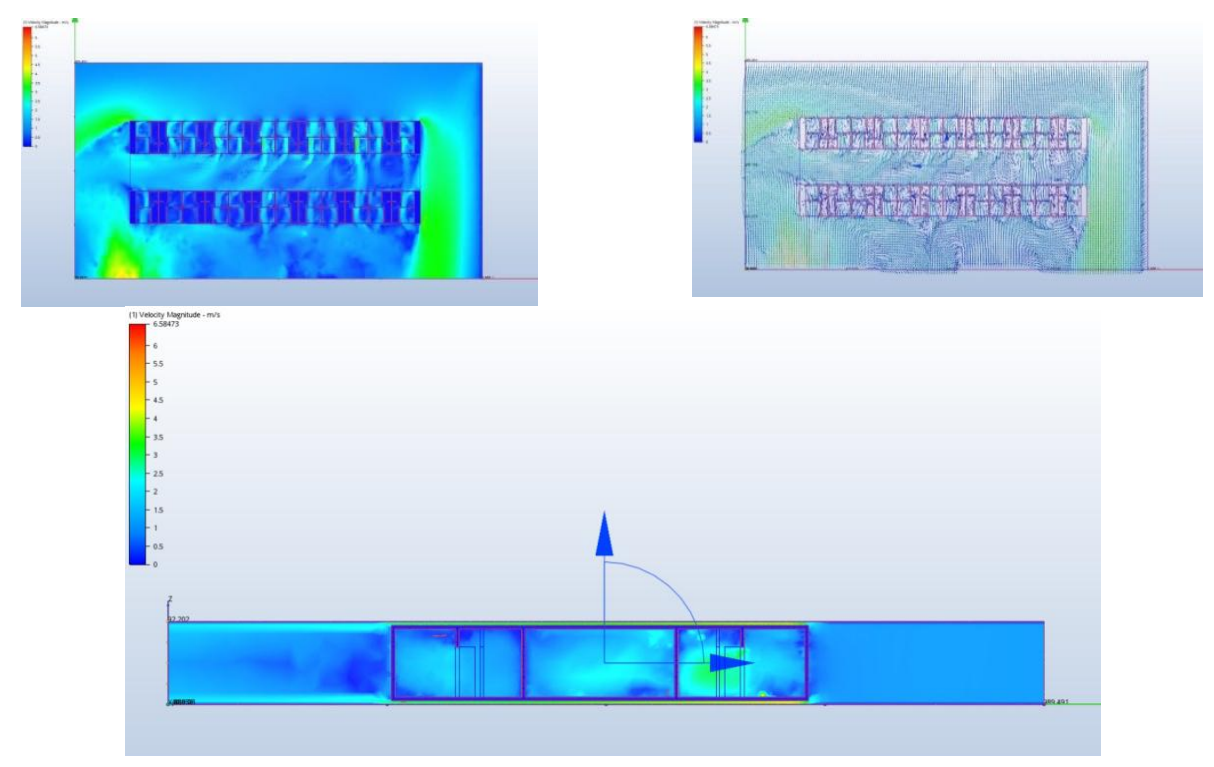

Figure 10. Analysis of Natural Ventilation on Double Load Corridor Sources : Author Analysis, 2019

From the picture above you can see air flowing from outside the building into the building through gaps and openings such as windows, doors, vents and corridor openings. When the air flows through the room, there is a change of air inside the room with air from outside the room. From the picture above also seen the speed and air pressure increase from outside the room when through the gap in the building and collide with the building. Changes in air velocity and pressure indicate the presence of airflow through a narrower space. So that the two models of the unit have the same cross-ventilation characteristics. The double load corridor has a higher wind speed than a single load with voids. This is due to the volume and size of the corridor room through which the wind in the double load corridor model is smaller, so the wind speed is greater. Whereas in the single load corridor model the wind speed is less because it has a larger volume of space for the corridor so that the wind entering the corridor will be spread in the void area.

\section{Analysis of daylight}

Daylight analysis is carried out to find out how much sunlight is entering the room. Daylight calculation is done by calculating the area of the area that receives more than 300 Lux sunlight according to SNI standards.

\section{Daylight Simulation Model}

In this simulation each model is simulated by the variation in unit orientation, to find out the percentage of daylight received. The simulation is done using 3 different 
times according to the position of the sun, which is March 5, where the sun is right at the equator, June 25, where the sun is north of the equator and December 24, where the sun is south of the equator.

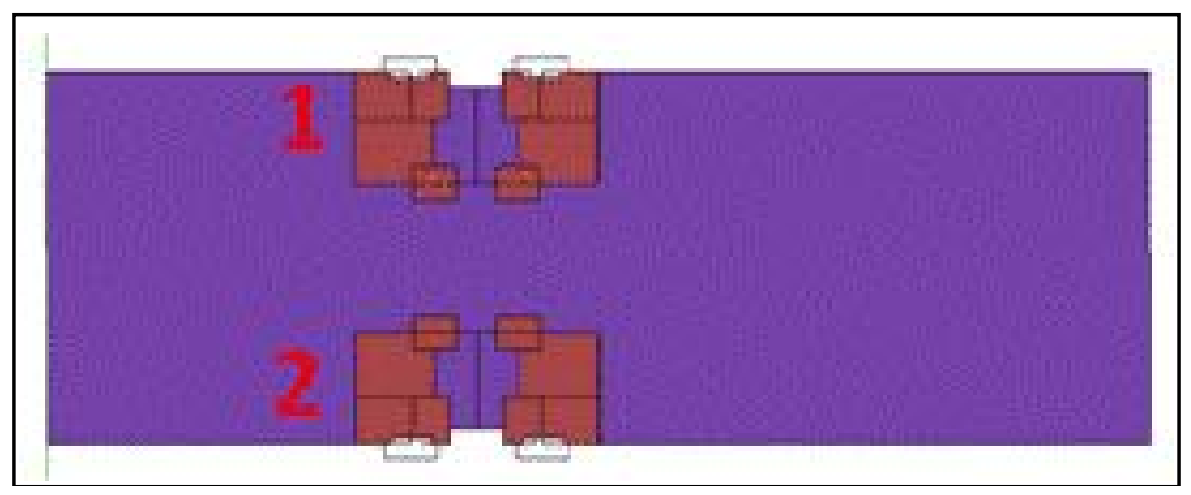

Figure 13. T-30 Flats Layout Model

Sources : Author Analysis, 2019

Table 3. Percentage of Daylight Earnings in Several Models or Flat Type

\begin{tabular}{|c|c|c|c|c|c|c|c|c|c|c|c|c|c|c|c|c|c|}
\hline \multirow{2}{*}{\multicolumn{2}{|c|}{$\begin{array}{l}\text { Orientasi } \\
\text { Kaca }\end{array}$}} & \multicolumn{2}{|c|}{ UTARA } & \multicolumn{2}{|c|}{ SELATAN } & \multicolumn{2}{|c|}{ TIMUR LAUT } & \multicolumn{2}{|c|}{ BARAT DAYA } & \multicolumn{2}{|c|}{ TIMUR } & \multicolumn{2}{|c|}{ BARAT } & \multicolumn{2}{|c|}{ TENGGARA } & \multicolumn{2}{|c|}{ BARAT LAUT } \\
\hline & & Clear & Panasap & Clear & Panasap & Clear & Panasap & Clear & Panasap & Clear & Panasap & Clear & \begin{tabular}{|l|} 
Panasap \\
\end{tabular} & Clear & Panasap & Clear & Panasap \\
\hline \multirow{2}{*}{$\begin{array}{l}\text { Area }>300 \text { Lux } \\
\text { tanggal } 5 \text { Maret }\end{array}$} & \begin{tabular}{|l|} 
Double Load corridor \\
No void
\end{tabular} & $46 \%$ & $31 \%$ & $46 \%$ & $31 \%$ & $46 \%$ & $31 \%$ & $46 \%$ & $31 \%$ & $46 \%$ & $31 \%$ & $46 \%$ & $31 \%$ & $46 \%$ & $31 \%$ & $46 \%$ & $31 \%$ \\
\hline & $\begin{array}{l}\text { Single Load corridor } \\
\text { With void }\end{array}$ & $47 \%$ & $32 \%$ & $47 \%$ & $32 \%$ & $47 \%$ & $32 \%$ & $47 \%$ & $32 \%$ & $47 \%$ & $32 \%$ & $47 \%$ & $32 \%$ & $47 \%$ & $32 \%$ & $47 \%$ & $32 \%$ \\
\hline \multirow{2}{*}{$\begin{array}{l}\text { Area }>300 \text { Lux } \\
\text { tanggal } 25 \text { Juni }\end{array}$} & $\begin{array}{l}\text { Double Load corridor } \\
\text { No void }\end{array}$ & $40 \%$ & $28 \%$ & $40 \%$ & $28 \%$ & $40 \%$ & $28 \%$ & $40 \%$ & $28 \%$ & $40 \%$ & $28 \%$ & $40 \%$ & $28 \%$ & $40 \%$ & $28 \%$ & $40 \%$ & $28 \%$ \\
\hline & \begin{tabular}{|l|} 
Single Load corridor \\
With void
\end{tabular} & $41 \%$ & $29 \%$ & $41 \%$ & $29 \%$ & $41 \%$ & $29 \%$ & $41 \%$ & $29 \%$ & $41 \%$ & $29 \%$ & $41 \%$ & $29 \%$ & $41 \%$ & $29 \%$ & $41 \%$ & $29 \%$ \\
\hline \multirow{2}{*}{$\begin{array}{c}\text { Area }>300 \text { Lux } \\
\text { tanggal } 24 \\
\text { Desember }\end{array}$} & \begin{tabular}{|l|}
$\begin{array}{l}\text { Double Load corridor } \\
\text { No void }\end{array}$ \\
\end{tabular} & $44 \%$ & $30 \%$ & $44 \%$ & $30 \%$ & $44 \%$ & $30 \%$ & $44 \%$ & $30 \%$ & $44 \%$ & $30 \%$ & $44 \%$ & $30 \%$ & $44 \%$ & $30 \%$ & $44 \%$ & $30 \%$ \\
\hline & \begin{tabular}{|l|} 
Single Load corridor \\
With void
\end{tabular} & $46 \%$ & $31 \%$ & $46 \%$ & $31 \%$ & $46 \%$ & $31 \%$ & $46 \%$ & $31 \%$ & $46 \%$ & $31 \%$ & $46 \%$ & $31 \%$ & $46 \%$ & $31 \%$ & $46 \%$ & $31 \%$ \\
\hline
\end{tabular}

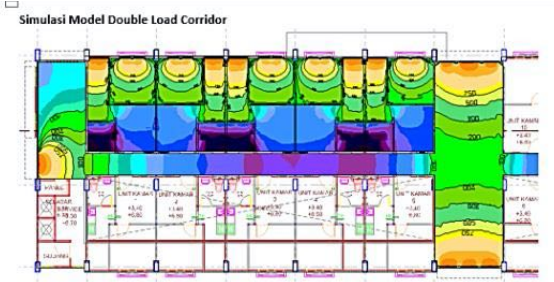

Gambar 59 Hasil Simulasi Daylight Model Douni 24 load Corridor

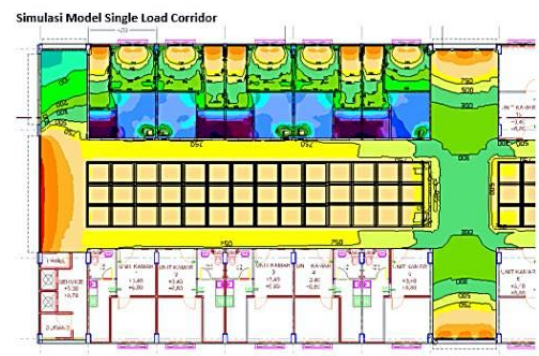

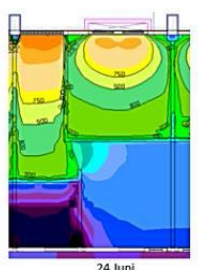

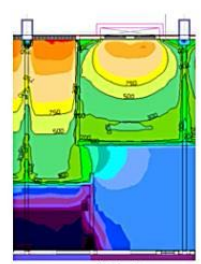

5 Maret
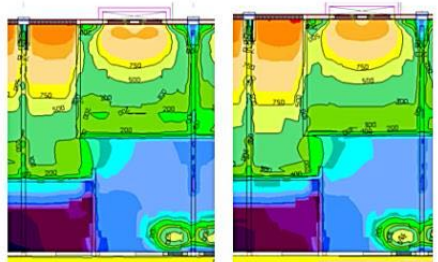

5 Mare
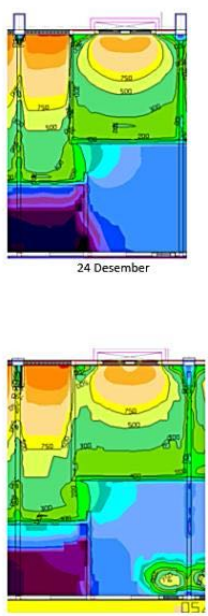

24 Desember

Figure 14. The daylight simulation results of the double load corridor Sources : Author Analysis, 2019 

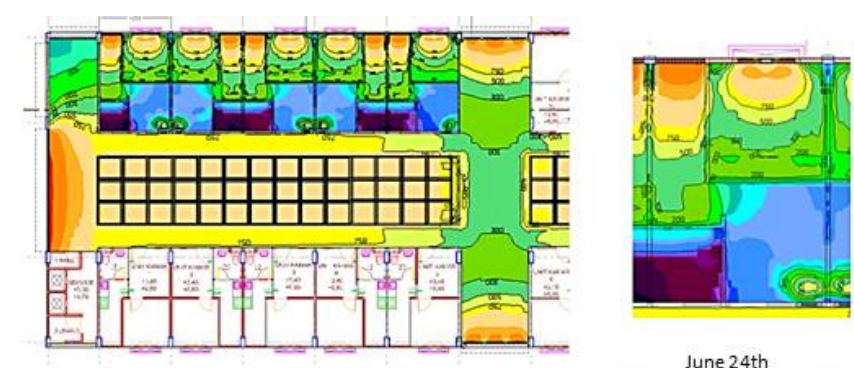

June 24 th

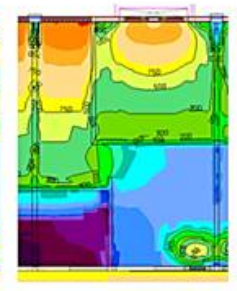

March 5th

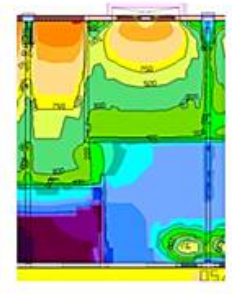

December 24th

Figure 15. The daylight simulation results of the single load corridor Sources : Author Analysis, 2019

Based on the dialux simulation results, the orientation of the building mass does not significantly influence the amount of daylight that enters the unit space. This is because the sky conditions in Indonesia tend to be cloudy so that the amount of sunlight obtained by units with different orientations does not have a significant difference. Then based on the difference in the glass window material used, it appears that the intensity of sunlight entering the unit using the tinted glass window (Panasap) is smaller than the intensity of the sunlight entering the unit using the clear glass window. Tinted glass (Panasap) has the ability to transmit sunlight smaller than clear glass. This can be seen from the SHGC value of tinted glass (Panasap) (0.584) which is smaller than that of clear glass (0.839). On clear glass with SHGC 0.839 it means that approximately $80 \%$ of the intensity of sunlight will enter and be passed into the building so that the greater the daylight that enters, but the greater the daylight that enters, the greater the heat of the sun that is felt.

\section{CONCLUSIONS}

The recommended flat layout model is a model with a double load corridor. When viewed in terms of development costs it is recommended to use the double load model because it can reduce the building site area so that it can be commercialized or utilized for other things. From the results of natural lighting simulation single load corridor models with voids the potential for natural light that evenly enters the whole room is greater than the double load model. It is just an additional note that this single load model is recommended to add openings in the living room area facing the corridor so that natural light from the corridor can enter the unit area with good distribution. The addition of these openings will have the potential to increase development costs. And if you look at the analysis of natural acceleration, between the double load and single load models both have a good air exchange pattern. Obtaining cross ventilation in both types can also be said to be the same. Only differ in the level of wind speed. But the size of the wind speed can not be used as a benchmark for the thermal comfort of its inhabitants. Because it is not certain that people will feel uncomfortable at low speeds or vice versa. So the existence of voids in the single load model does not guarantee to have a better wind flow direction compared to the double load model. The recommended orientation is to face north- 
south, so as minimum as possible to avoid the large openings in the direction of the heat coming of the sun i.e. east-west direction. The south orientation receives the lowest heat gain compared to other orientations, so that the amount of solar heat transmitted into the building is smaller than the direction facing the east-west. But for daylight acquisition, the direction of this orientation has no effect on the size of the daylight in the room.

\section{REFERENCES}

National Standardization Agency. (2001a) SNI 03-2396-2001 on Procedures for Designing Natural Lighting Systems in Buildings.

National Standardization Agency. (2001b) SNI 03-6575-2001 ON concerning Procedures for Designing Artificial Lighting Systems in Buildings.

National Standardization Agency Jakarta Badan Standarisasi Nasional. (2004) SNI 03-1733-2004 concerning Procedures for Planning a Housing Environment in the Urban Area.

National Standardization Agency Jakarta Dharmaraty, Ashri. (2009) Concept of Prototype Design in Rusunawa Building Design, The State Ministry of Public Housing of the Republic of Indonesia, Jakarta Ministry of Public Works. 2007.

Ministry of Public Works Regulation No. 5 of 2007 concerning Technical Guidelines for the Construction of High-rise Simple Flats, Ministry of Public Works, Jakarta

Ministry of Public Works Regulation No. 5 of 2007 concerning Technical Guidelines for the Construction of High-rise Simple Flats, Ministry of Public Works. Jakarta

Christensen, Jørgen E. (2008) A Method for a more specific Simulation of Operative Temperature in Thermal Analysis Programmes, Denmark: Technical University of Denmark. 20 
Nurina: STUDY OF "RUSUN" TYPOLOGY BASED ON THERMAL COMFORT ANALYSIS USING SOFTWARE SIMULATION METHOD IN RUSUNAWA TYPE-30

This Page is Intentionally Left Blank 